\title{
PENERAPAN MODEL TEMAN SEBAYA GUNA MENINGKATKAN PENGETAHUAN SISWA DALAM PENGELOLAAN OBAT DI SMA N 1 MERTOYUDAN
}

Tiara Mega Kusuma, dan Heni Lutfiyati,

${ }^{1}$ Program Studi Farmasi S-1 Universitas Muhammadiyah Magelang

E-mail: tiaramega@ummgl.ac.id

\begin{abstract}
ABSTRAK. Ikatan Apoteker Indonesia mencetuskan program DAGUSIBU (Dapatkan Gunakan Simpan Buang) Obat dengan baik dan benar sebagai slogan pengelolaan obat dengan baik dan benar dalam rangka mengoptimalkan terapi dan mencegah penyalahgunaan obat pada masyarakat. Model teman sebaya terbukti mampu meningkatkan efektivitas penyampaian pesan kepada teman seumuran. Model Apoteker sebaya dipilih untuk meningkatkan pengetahuan siswa SMA N 1 Mertoyudan tentang pengelolaan obat. Apoteker sebaya dipilih dari 36 siswa yang tergabung dalam keanggotaan PMR (Palang Merah Remaja) di sekolah. Proses seleksi dilakukan dengan metode wawancara yang meliputi pendalaman tingkat motivasi dan keterampilan komunikasi siswa serta dilakukan dengan tes tertulis. Sebanyak 12 siswa dengan tingkat motivasi dan ketrampilan komunikasi yang tertinggi dipilih untuk selanjutnya dilakukan skrinning berdasarkan hasil tes tertulis. Sebanyak 6 siswa yang terpilih dalam Apoteker Sebaya diberikan materi dan pelatihan tentang DAGUSIBU obat dengan baik dan benar. Pendampingan sosialisasi oleh Apoteker Sebaya di kelompok siswa menunjukkan peningkatan tingkat pengetahuan tentang obat sebelum dan sesudah dilakukan penyuluhan. Hasil ini menunjukkan adanya efektivitas pengembangan model Apoteker Sebaya
\end{abstract}

Kata kunci: apoteker; teman sebaya; pengelolaan obat

ABSTRACT. Indonesian Pharmacists Association initiated DAGUSIBU (Get, Use, Save, Removal) programs as a term for managing drugs to optimize therapy and to prevent drug abuse in the community. Peer models has proved to be able to increase the effectiveness of delivering messages to friends of the same age. Pharmacist peer group models has been choosed to increase managing drugs knowledges of students in SMA N 1 Mertoyudan. Pharmacist Peer Group were selected from 36 students who were members of the PMR membership in the school. The selection process is carried out by interview method which includes deepening the level of motivation and communication skills of students, and by written test. Twelve students with the highest level of motivation and communication skills were selected for subsequent screening based on the highest score of the written test results. Amount 6 students selected in Pharmacists Peer Group were given material and training about DAGUSIBU. Mentoring socialization by Pharmacists Peer Group in the student group shows the results of an increase in the level of knowledge about drugs before and after counseling. These results indicate the effectiveness of the development of Pharmacists Peer Group models.

Key words: pharmacist; peer group; managing drugs

\section{PENDAHULUAN}

Ikatan Apoteker Indonesia (IAI) sebagai wadah organisasi profesi apoteker mencanangkan kegiatan penyuluhan terkait pengelolaan obat yang baik dan benar kepada masyarakat luas, baik remaja maupun dewasa sebagai salah satu peranan apoteker dalam bidang farmasi sosial. Kegiatan ini diberi nama DAGUSIBU yang merupakan singkatan dari "Dapatkan, Gunakan, Simpan, dan Buang" obat dengan baik dan benar. Tujuan kegiatan penyuluhan pengelolaan obat yang baik dan benar adalah agar masyarakat mendapatkan terapi yang optimal. Selain itu, juga untuk menghindari penyalahgunaan obat yang semakin meningkat tiap tahunnya akibat membuang bekas obat dengan tidak benar (Anonim, 2014).

Termasuk dalam kelompok risiko tinggi terhadap penyalahgunaan obat adalah remaja. Masa remaja berlangsung dari usia 10-19 tahun dan merupakan masa dimana tingkat rasa ingin tahu sangat tinggi. Informasi yang salah maupun pengetahuan yang kurang tentang pengelolaan obat yang benar dapat mengakibatkan persepsi menjadi salah. Hal ini bisa menjadi salah satu indikator meningkatnya penyalahgunaan obat pada kalangan remaja (Afandi, Chandra, Novitasari, Widjaja, \& Kurniawan, 2009).
Pengetahuan dan keterampilan yang didapatkan oleh siswa dipengaruhi oleh faktor internal dan faktor eksternal. Faktor eksternal meliputi lingkungan sosial sekolah dan keluarga. Adapun lingkungan sosial sekolah salah satunya adalah keberadaan teman sebaya. Keberadaan teman sebaya mampu memberikan motivasi sekaligus suasana yang membangun, mempengaruhi, dan memberikan rasa yang lebih nyaman untuk menerima informasi karena kesamaan umur, sehingga diharapkan informasi yang diberikan akan terserap lebih baik. Pada masa remaja hubungan dengan kelompok teman sebaya menjadi hal yang sangat penting, bahkan lebih erat dibandingkan hubungannya dengan orang tua (Buzarudina, 2013; Fitra, 2013).

SMA Negeri 1 Mertoyudan merupakan salah satu SMA Negeri di Kabupaten Magelang yang terletak di kecamatan Mertoyudan. SMA Negeri 1 Mertoyudan berdiri tahun 1971 atas prakarsa Gubernur Akademi Militer bekerja sama dengan Pemerintah Daerah Tingkat II Kabupaten Magelang. SMAN 1 Mertoyudan berstatus akreditasi A dengan salah satu fasilitas prasarana yang disediakan adalah UKS (Unit Kesehatan Siswa) yang terkelola sudah cukup baik. Namun demikian, fasilitas pelayanan kesehatan, khususnya apotek di lingkungan 
sekolah tidak tersedia. Apotek terdekat berada di luar lingkungan sekolah, di sepanjang jalan MagelangPurworejo dengan jarak $\pm 4 \mathrm{~km}$.

Berdasarkan latar belakang di atas, maka dirasa perlu untuk menerapkan model Apoteker sebaya untuk meningkatkan pengetahuan siswa tentang pengelolaan obat dengan baik dan benar di SMA N 1 Mertoyudan mengingat lokasi yang cukup jauh dari fasilitas kesehatan. Diharapkan dengan terbentuknya model Apoteker Sebaya, sosialisasi DAGUSIBU akan lebih efektif dan efisien.

\section{METODE}

Secara umum, metode yang diterapkan dalam pelaksanaan pengabdian ini meliputi pendidikan dan pelatihan. Metode pendidikan berupa penyuluhan dan pelatihan tentang obat diterapkan untuk mempersiapkan kader apoteker sebaya yang terpilih. Adapun tahapan pelaksanaan kegiatan pengabdian yang dilakukan meliputi:

\section{Seleksi kader apoteker sebaya}

a. Seleksi dilakukan terhadap 35 siswa yang tergabung dalam organisasi PMR (Palang Merah Remaja) di Sekolah Menengah Atas Negeri 1 Mertoyudan.

b. Dipilih sebanyak 12 siswa dengan kemampuan komunikasi dan motivasi yang tertinggi yang dilakukan melalui metode wawancara.

c. Sebanyak 5 siswa dengan perolehan skor tes tertulis tentang obat yang tertinggi, dipilih sebagai Kader Apoteker Sebaya.

\section{Penyiapan Kader Apoteker Sebaya Terpilih}

a. Pemberian materi tentang DaGuSiBu (Dapatkan, Gunakan, Simpan, Buang) Obat dengan benar oleh Apoteker 1.

b. Pemberian pelatihan dengan cara memberikan jenis obat untuk kemudian dilakukan identifikasi tentang golongan obat, tempat obat dapat diperoleh, bentuk sediaan dan bagaimana cara penggunaan, serta bagaimana cara menyimpan dan membuang obat dengan baik dan benar oleh Apoteker 2 .

3. Pendampingan Praktek Apoteker Sebaya terhadap Kelompok Siswa

a. Praktek langsung ini dilakukan terhadap kelompok siswa sejumlah 37 orang dari perwakilan berbagai kelas.

b. Penyampaian materi dilakukan oleh Apoteker Sebaya dengan didampingi oleh tim pelaksana pengabdian kepada masyarakat.

c. Efektivitas penyampaian materi oleh Apoteker Sebaya diukur berdasarkan ada tidaknya peningkatan persentase siswa dengan pengetahuan baik dan tidak baik. Kategori penggolongan tingkat pengetahuan disajikan pada Tabel 1.
Tabel 1. Kategori Variabel

\begin{tabular}{rll}
\hline Variabel & \multicolumn{1}{c}{ Coding } & \multicolumn{1}{c}{ Kriteria } \\
\hline Pengetahuan & Baik & jawaban soal benar $\geq 70 \%$ \\
& Tidak Baik & jawaban soal benar $<70 \%$ \\
\hline
\end{tabular}

Soal yang diberikan untuk pretest dan posttest merupakan jenis soal yang sama dengan jumlah total soal sebanyak 20 yang pengelompokkannya dapat dilihat pada Tabel 2

Tabel 2. Pengelompokkan Soal

\begin{tabular}{lc}
\hline Pengelompokkan Soal DaGuSiBu & $\begin{array}{c}\text { Jumlah } \\
\text { Soal }\end{array}$ \\
\hline $\begin{array}{l}\text { Dapatkan } \\
\text { Cara mendapatkan obat yang baik dan benar: } \\
\text { penggolongan dan penyalur obat }\end{array}$ & 5 \\
$\begin{array}{l}\text { Gunakan } \\
\text { Penggunaan obat yang baik dan benar: aturan dan cara } \\
\text { pakai obat umum dan obat dengan teknik khusus }\end{array}$ & 5 \\
$\begin{array}{l}\text { Simpan } \\
\text { Penyimpanan obat yang baik dan benar: } \\
\text { klasifikasi suhu penyimpanan obat } \\
\text { Buang } \\
\text { Cara membuang obat yang baik dan benar: } \\
\text { obat cair, padat, dan antibiotik }\end{array}$ & 5 \\
\hline
\end{tabular}

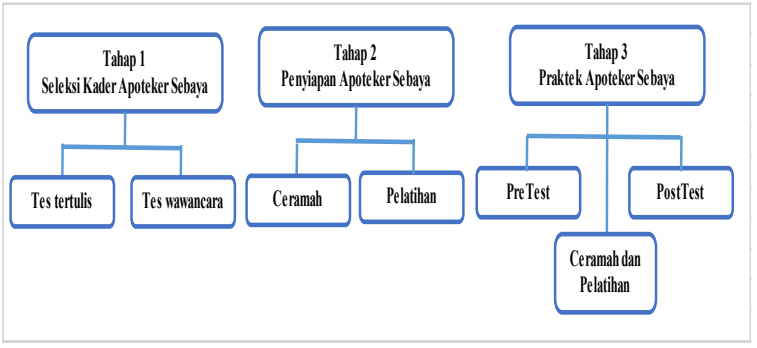

Gambar 1. Tahapan Pelaksanaan Kegiatan Pengabdian di SMA N 1 Mertoyudan

\section{HASIL DAN PEMBAHASAN}

\section{Seleksi Kader Apoteker Sebaya}

Model teman sebaya dipilih karena menurut beberapa penelitian terbukti dapat meningkatkan efektivitas penyampaian pesan. Hubungan peer group atau kelompok sebaya diyakini lebih erat dibandingkan dengan orang tua (Arjanggi, 2010; Usman, 2013).

Seleksi kader Apoteker Sebaya dilakukan terhadap 35 siswa kelas X dan XI yang tergabung dalam organisasi PMR(Palang Merah Remaja) di sekolah. Seleksi dilakukan menggunakan metode test dan wawancara. Poin penilaian dari wawancara meliputi motivasi siswa untuk dijadikan Apoteker Sebaya, serta kemampuan komunikasi siswa. Sedangkan poin penilaian test terdiri dari pengetahuan tentang obat secara umum.

Motivasi dan ketrampilan komunikasi siswa dipilih menjadi skrining pertama yang dilakukan oleh tim pelaksana pengabdian. Hal ini didasarkan bahwa motivasi akan mempengaruhi pencapaian tujuan yang dikehendaki dari tim pelaksana pengabdian. Motivasi yang tinggi merupakan modal awal siswa untuk berkomitmen 
mengikuti seluruh rangkaian proses kegiatan dan memberikan penggerak untuk mencapai tujuan yang telah ditetapkan. Dari beberapa penelitian diketahui bahwa motivasi dapat meningkatkan kualitas kinerja (Efendy, 2010; Hamdu \& Agustina, 2011; Kiswoyowati, 2011).

Komunikasi menjadi bagian yang tidak kalah penting karena akan memengaruhi efektivitas penyampaian materi. Komunikasi efektif diperlukan agar informasi atau pesan yang disampaikan dapat dimengerti oleh audiens. Komunikasi efektif dipandang sebagai suatu hal yang penting dan kompleks. Dianggap penting karena ragam dinamika kehidupan biasanya menghadirkan situasi kritis yang perlu penanganan secara tepat (Usman, 2013; Wahyuni, 2015). Apoteker dituntut untuk memiliki jiwa nine star, dimana salah satunya adalah memposisikan diri sebagai decission maker. Sehingga kader Apoteker Sebaya harus memiliki modal ketrampilan komunikasi yang baik.

Berdasarkan hasil wawancara diambil 12 siswa dengan motivasi dan ketrampilan komunikasi tertinggi. Sebanyak 12 siswa yang terpilih pada tahapan ini akan diskrinning kembali menjadi 6 siswa yang akan dipilih sebagai kader Apoteker Sebaya berdasarkan skor perolehan tes tertulis yang tertinggi. Pengetahuan dipertimbangkan menjadi skrinning kedua karena pengetahuan pada dasarnya akan diberikan saat pelatihan. Tingkat pengetahuan kader Apoteker Sebaya ini juga menjadi pijakan pertama tim pelaksana pelaksana pengabdian untuk merancang metode dan kedalaman materi yang paling cocok diberikan dengan mempertimbangkan kemampuan awal siswa.

\section{Penyiapan Apoteker Sebaya Terpilih}

Berdasarkan teori belajar, kegiatan belajar meliputi pengetahuan, ketrampilan, sosial, dan pemecahan masalah. Pengetahuan diperoleh dengan pemberian materi. Kemampuan berupa ketrampilan diperoleh Apoteker Sebaya dengan cara pelatihan. Sedangkan kemampuan sosial dan pemecahan masalah dilatih melalui kegiatan praktek langsung Apoteker Sebaya memberikan penyuluhan kepada kelompok siswa.

Pemberian materi dan pelatihan diberikan oleh tim pelaksana pengabdian, Apoteker Tiara Mega Kusuma dan Apoteker Heni Lutfiyati tentang $\mathrm{DaGuSiBu}$ obat dengan baik dan benar. DaGuSiBu merupakan jargon yang dicetuskan oleh IAI (Ikatan Apoteker Indonesia) yang merupakan singkatan dari Dapatkan, Gunakan, Simpan, dan Buang Obat dengan benar. Program ini dicetuskan karena melihat kondisi masyarakat saat ini yang masih rendah tentang bagaimana cara pengelolaan obat yang baik dan benar, serta sebagai salah satu upaya mencegah peredaran obat palsu. Pengelolaan obat ini dimulai dari bagaimana cara mendapatkan, menggunakan, menyimpan, dan membuang obat dengan baik dan benar.

Penyiapan Apoteker Sebaya diawali dengan pemberian materi tentang definisi umum obat dan penggolongannya. Apoteker Sebaya diharapkan dapat membedakan penggolongan obat dan bagaimana cara mendapatkannya. Apoteker Sebaya ditekankan pentingnya untuk mendapatkan obat di tempat yang tepat untuk menghindari penggunaan obat yang tidak rasional.

Materi kedua berupa penggolongan obat menurut bentuk sediaan dan cara penggunaan obat yang tepat. Misal pada penggunaan obat-obat dengan teknik khusus yang sering diresepkan, seperti sediaan inhaler, supositoria, dan lain sebagainya. Kemudian Apoteker Sebaya juga diberikan pemahaman tentang aturan pakai obat yang tepat. Misal pada resep tertulis $3 \times 1$, maka obat diminum tiap 8 jam. Hal ini untuk menjaga kadar obat di dalam darah sehingga efektivitas terapi tercapai. Selain itu untuk pemakaian antibiotik, maka obat harus dihabiskan sebagai upaya mencegah resistansi obat. Untuk obat yang sifatnya hanya sebagai terapi supportif, maka digunakan hanya bila diperlukan. Misal obat sakit kepala parasetamol, maka hanya digunakan pada saat pusing atau demam saja.

Penyimpanan obat juga menjadi materi yang penting, karena banyak masyarakat yang belum tahu bagaimana penyimpanan obat yang tepat. Selama ini masyarakat beranggapan bahwa menyimpan obat yang benar adalah disimpan di dalam lemari pendingin. Padahal penyimpanan obat disesuaikan dengan karakteristik obat dan dapat dilihat cara penyimpanannya di kemasan obat. Apoteker Sebaya juga diberikan pemahaman tentang adanya perbedaan masa simpan antara obat yang masih disegel dengan yang sudah dibuka.

Peredaran obat palsu yang semakin marak, salah satunya disebabkan karena pembuangan wadah obat yang tidak tepat. Pembuangan obat yang tidak tepat juga dapat merusak lingkungan. Pemusnahan obat dapat dilakukan dengan beberapa cara tergantung dari bentuk sediaan dan wadah, misal ada yang ditimbun atau dibakar. Sehingga cara membuang obat yang tepat juga perlu untuk disampaikan kepada Apoteker Sebaya untuk nantinya dapat disosialisasikan kepada kelompok siswa.

\section{Pendampingan Sosialisasi Apoteker Sebaya kepada Kelompok Siswa}

Untuk memastikan bahwa apoteker sebaya yang sudah dilatih dan diberikan materi telah memiliki kemampuan pengetahuan dan ketrampilan minimal yang diharapkan oleh tim pelaksana pengabdian, maka apoteker sebaya diminta untuk melakukan praktik langsung memberikan penyuluhan dan pelatihan kepada kelompok siswa sejumlah 37 yang terdiri dari perwakilan kelas X, kelas XI, dan kelas XII.

Melalui kegiatan praktik langsung diharapkan apoteker sebaya mendapatkan pengalaman melalui interaksi langsung dengan obyek. Namun kelemahan dari metode praktik langsung bila tidak dilakukan pembimbingan maka kendala atau kelemahan apoteker sebaya tidak bisa diidentifikasi. Sehingga dalam hal ini, apoteker sebaya tetap dilakukan pendampingan oleh tim pelaksana pengabdian. 
Metode penyuluhan digunakan dalam kegiatan ini karena menurut penelitian yang dilakukan oleh (Pasaribu, 2005; Pratiwi Hartono, Saptaning Wilujeng, \& Andarini, 2015), metode ceramah diketahui dapat meningkatkan pengetahuan siswa lebih baik dibandingkan dengan metode buku, meskipun tidak terdapat perbedaan bermakna. Namun demikian, metode ceramah memiliki kelebihan dimana komunikasi terjadi secara langsung sehingga memungkinkan terjadinya dialog interaktifantara pemateri dan audiens. Kelebihan ini tidak didapatkan dengan penyampaian informasi melalui jalur komunikasi pasif, misal melalui media buku dan leaflet.

Kegiatan sosialisasi diakhiri dengan sesi tanya jawab dan posttest. Respon pelajar terhadap penyampaian materi oleh Apoteker Sebaya dikatakan cukup baik. Hal ini terlihat dari banyaknya pertanyaan dari pelajar kepada Apoteker Sebaya yang menunjukkan rasa keingintahuan pada siswa mengenai pengelolaan obat yang baik dan benar.

Efektivitas penyampaian materi oleh Apoteker Sebaya, juga terlihat dari hasil pretest dan dibandingkan dengan hasil posttest kepada kelompok siswa. Pretest dilakukan sebelum Apoteker Sebaya melakukan penyuluhan. Sedangkan posttest dilakukan setelah dilakukan penyuluhan. Poin pertanyaan antara pretest dan posttest dibuat sama, sehingga pelatih dapat mengetahui ada tidaknya pengaruh pemberian materi oleh Apoteker Sebaya terhadap pengetahuan kelompok siswa.

Hasil pretest menunjukkan 62\% siswa memiliki pengetahuan yang kurang baik tentang obat dan 38\% memiliki pengetahuan yang baik tentang obat. Sedangkan hasil postets menunjukkan $75 \%$ siswa memiliki pengetahuan yang baik dan $25 \%$ pengetahuan kurang baik. Hasil ini menunjukkan adanya pengaruh antara sebelum dan sesudah diberikan pemberian materi dan pelatihan dengan penerapan model Apoteker Sebaya.

\section{SIMPULAN}

Penerapan model Apoteker Sebaya yang dipilih dengan kriteria motivasi dan ketrampilan komunikasi yang tinggi, serta tingkat pengetahuan tentang obat yang cukup terbukti mampu meningkatkan pengetahuan kelompok siswa sebanyak 37 siswa di SMAN 1 Mertoyudan tentang pengelolaan obat. Hal ini dibuktikan dengan nilai pretest dan postets mahasiswa yang memiliki pengetahuan yang tinggi sebesar $75 \%$ yang semula hanya 38\%. Efektifitas model apoteker sebaya juga terlihat dari banyaknya pertanyaan dari kelompok siswa yang menunjukkan antusias siswa terhadap materi yang diberikan.

\section{UCAPAN TERIMAKASIH}

Kegiatan pengabdian ini merupakan pendanaan Program Kemitraan Universitas (PKU) Tahun 2017/2018 dari LP3M Universitas Muhammadiyah Magelang.

\section{DAFTAR PUSTAKA}

Afandi, D., Chandra, F., Novitasari, D., Widjaja, I. R., \& Kurniawan, L. (2009). Tingkat Penyalahgunaan Obat dan Faktor Risiko di Kalangan Siswa Sekolah Menengah Umum. Majalah Kedokteran Indonesia, 59, (6).

Anonim. (2014). Sinergisme Program Badan POM dengan Ikatan Apoteker Indonesia. Retrieved from http://www.pom.go.id/mobile/index.php/view/ berita/7047/Sinergisme-Program-Badan-POM-RIdengan-Ikatan-Apoteker-Indonesia.html

Arjanggi, R. (2010). Metode Pembelajaran Tutor Teman Sebaya Meningkatkan Hasil Belajar Berdasar Regulasi-Diri The Effectiveness of Peer Tutoring Method on Self-Regulated Learning Abstract. Makara Sosial Humaniora, 14, (2), 91-97.

Buzarudina, F. (2013). Remaja Terhadap Tingkat Pengetahuan Siswa Sman 6 Kecamatan Pontianak Timur Tahun 2013 Program Studi Pendidikan Dokter.

Efendy, M.T. (2010). Pengaruh kompetensi, independensi, dan motivasi terhadap kualitas audit aparat inspektorat dalam pengawasan keuangan daerah (. Universitas Diponegoro.

Fitra, N.A. (2013). Pengaruh Penyuluhan Terhadap Peningkatan Pengetahuan Kesehatan Reproduksi Remaja di SMA PGRI 3 Purwakarta. Universitas Muhammadiyah Surakarta.

Hamdu, G., \& Agustina, L. (2011). Pengaruh Motivasi Belajar Siswa Terhadap Prestasi Belajar IPA di Sekolah Dasar. Jurnal Penelitian Pendidikan, 12, (1), 81-86.

Kiswoyowati. (2011). Pengaruh Motivasi Belajar dan Kegiatan Belajar Siswa Terhadap Kecakapan Hidup Siswa. Edisi Khusus, (1), 120-126.

Pasaribu, H.E. (2005). Perbandingan Penyuluhan Kesehatan Metode Ceramah Tanya Jawab Dengan Penyuluhan Kesehatan Menggunakan Buku Kecacingan Dalam Mencegah Reinfeksi Ascaris lumbricoides Pada Anak Sekolah Dasar. Universitas Diponegoro.

Pratiwi Hartono, N., Saptaning Wilujeng, C., \& Andarini, S. (2015). Pendidikan Gizi tentang Pengetahuan Pemilihan Jajanan Sehat antara Metode Ceramah dan Metode Komik. Indonesian Journal of Human Nutrition, 2(2), 76-84.

Usman, I. (2013). Kepribadian, komunikasi, kelompok teman sebaya, iklim sekolah dan perilaku. Humanitas, $x$, (1).

Wahyuni, E. (2015). Hubungan Self-Effecacy dan Keterampilan Komunikasi. Jurnal Komunikasi Islam, 05, (1). 